\title{
EGFR TKI as first-line treatment for patients with advanced EGFR mutation-positive non-small-cell lung cancer
}

\author{
Xueli Nan ${ }^{1,2}$, Chao Xie ${ }^{2}$, Xueyan Yu³ and Jie Liü ${ }^{2,4}$ \\ ${ }^{1}$ School of Medicine and Life Sciences, University of Ji'nan-Shandong Academy of Medical Sciences, Shandong, China \\ ${ }^{2}$ Department of Oncology, Shandong Cancer Hospital Affiliated to Shandong University, Shandong, China \\ ${ }^{3}$ Department of Oncology, Shandong Provincial Chest Hospital, Shandong, China \\ ${ }^{4}$ Shandong Academy of Medical Sciences, Shandong, China
}

Correspondence to: Jie Liu, email: lj1260814@126.com

Keywords: EGFR TKI, first-line treatment, non-small-cell-lung cancer, EGFR mutations, combined therapy

Received: February 21, 2017

Accepted: July 26, 2017

Published: August 09, 2017

Copyright: Nan et al. This is an open-access article distributed under the terms of the Creative Commons Attribution License 3.0 (CC BY 3.0), which permits unrestricted use, distribution, and reproduction in any medium, provided the original author and source are credited.

\section{ABSTRACT}

\begin{abstract}
After the discovery of activating mutations in EGFR, EGFR tyrosine kinase inhibitors (TKIs) have been introduced into the first-line treatment of non-small-cell lung cancer (NSCLC). A series of studies have shown that EGFR TKI monotherapy as first-line treatment can benefit NSCLC patients harbouring EGFR mutations. Besides, combination strategies based on EGFR TKIs in the first line treatment have also been proved to delay the occurrence of resistance. In this review, we summarize the scientific literature and evidence of EGFR TKIs as first-line therapy from the firstgeneration EGFR TKIs to conceptually proposed fourth-generation EGFR TKI, and also recommend the application of monotherapy and combination therapies of the EGFRbased targeted therapy with other agents such as chemotherapy, anti-angiogenic drugs and immunecheckpoint inhibitors.
\end{abstract}

\section{INTRODUCTION}

Non-small-cell lung cancer (NSCLC) is believed as one of the main reasons that cause deaths from cancer worldwide. According to statistics, the quantity of new lung cancer is expected to reach 222,500 in the United States in 2017 [1]. Before introducing genomic epidermal growth factor receptor (EGFR) inhibitor therapy, despite platinum-based combination chemotherapy, the overall survival (OS) of most patients with advanced non-smallcell lung cancer (NSCLC) is less than one year [2]. With the deep understanding of EGFR gene mutations, the treatment of NSCLC has entered an era of co-directed therapy by histology and genotyping, which allows patients to obtain personalized molecular targeted therapies [3].

The HER family includes EGFR, HER2 (ErbB2), HER (ErbB3) and HER4 (ErbB4). Through combining with its ligands, the EGFR takes shape dimers with other EGFR or other HER family members and experiences autophosphorylation at the crucial tyrosine residues, leading to activation of some downstream signalling pathways, which mediates a variety of cellular processes, including proliferation, survival and apoptosis. EGFR signaling can be constitutively activate through genic mutation or genic amplification or both, which has been shown to be closely related to the occurrence, progression and poor prognosis of NSCLC [4-6]. Besides, there have studies demonstrated activation mutations in the tyrosine kinase domain of EGFR and this percentage of mutations may range from $15 \%$ to $40 \%$, particularly common in Asian, female, never or light smoking NSCLC [7-10]. More than $90 \%$ of the known activating EGFR mutations are deletion of exon 19 (in-frame) and point mutation of exon 21 (L858R) [4, 5]. Subsequent clinical studies have demonstrated that these two mutations have different susceptibilities to TKIs treatment [11-13].

After the discovery of the EGFR gene, EGFR tyrosine kinase inhibitors (TKIs) have also been published one after another. EGFR TKIs have been recommend by the American Society of Clinical Oncology (ASCO), the European Society for Medical Oncology (ESMO), and the National Comprehensive Cancer Network (NCCN) as a potential first-line treatment for advanced NSCLC 
patients with EGFR mutations positive. Recently, a considerable number of clinical studies are designed to assess the efficacy and safety of different types and different treatment modalities of EGFR TKIs as first-line treatment for NSCLC. In this review, our goal is to help clinicians make decisions in consideration of existing evidences and provide forthcoming methods for patients harboring EGFR mutations.

\section{EGFR TKI monotherapy}

EGFR TKI monotherapy has become the recommended treatment strategy and the cornerstone of combined therapy for NSCLC patients harboring EGFR mutation.

\section{EGFR TKI versus chemotherapy}

Compared with traditional platinum-based combination chemotherapy, EGFR TKI unprecedentedly brought a better clinical benefit and quickly laid its own position in treating advanced non-small cell lung cancer patients with EGFR mutation.

\section{First-generation EGFR TKIs}

The working mechanism of first-generation EGFRTKIs is to block the activation of downstream signaling induced by EGFR through binding to the ATP-binding sites.

\section{Gefitinib}

Gefitinib is considered as an oral first-generation EGFR TKI. In 2015, gefitinib was approved by USFDA as a first-line treatment for metastatic NSCLC patients with activating EGFR mutations [14]. There are four major studies supporting gefitinib as first-line therapy for NSCLC harboring EGFR mutations [15-18]. The IPASS (Iressa Pan-Asia Study) [15] was regarded as the milestone for the clinical application of EGFR TKI, because it was the first randomized clinical trial to compare EGFR-TKI with chemotherapy at first-line treatment for advanced NSCLC with adenocarcinoma. The final results reported that improved progression-free survival (PFS) was inferior in the chemotherapy arm than the gefitinib arm. However, the overall survival (OS) was no difference comparing the overall population with EGFR mutation-positive patients [18.8 months vs. 17.4 months hazard ratio (HR), 0.90; 95\% confidence intervals (CI), 0.79 to 1.02 ; $P<0.109]$. Interestingly, the PFS benefit only existed in the EGFR mutation positive subgroup (median 9.5 vs. 6.3 months, HR 0.48 [0.36-0.64], $p<0.001$ ) not in the EGFR mutation negative subgroup (median 1.5 vs. 5.5 months, HR 2.85 [2.05-3.98], $p<0.001$ ) than chemotherapy. The final finding considered that EGFR mutation could predict the response to gefitinib, so it may be the most promising predictive biomarker. The outcomes of First-SIGNAL, NEJ002 and WJTOG3405 trials [16-18] were same to those of IPASS in NSCLC patients carrying positive EGFR mutation through comparing gefitinib with doublet chemotherapy as first-line therapy. In these studies, rash, diarrhea and liver dysfunction were the most common adverse events (AEs) reported with gefitinib. In addition, interstitial lung disease was rare but fatal. However, the longer PFS did not turn into OS advantage - the reason behind this failure could be the result of a cross-over effect. Moreover, these studies established EGFR mutation status can replace clinical predictors to become more valuable predictive factor and recommended gefitinib as the first-line treatment for NSCLC with EGFR mutation.

\section{Erlotinib}

Erlotinib is an reversibly oral EGFR-TKI and it received approval from FDA as a first-line treatment for patients with EGFR mutation in 2013. Be different from gefitinib in Asian population, EURTAC [19] was the primary trial to prove the Caucasian population can also benefit from EGFR TKI as first-line treatment. In the present study, the researchers randomized 173 NSCLC patients with EGFR mutations to erlotinib and chemotherapy. The median PFS (primary endpoint) was 9.7 months in erlotinib set longer than $5 \cdot 2$ months in chemotherapy set at time cut-off (HR $0 \cdot 37,95 \%$ CI $0 \cdot 25-0 \cdot 54 ; p<0 \cdot 0001)$. Similar to gefitinib, OS was no significant difference between two groups, too. The data was 22.9 months in EGFR TKI block in comparison with 18.8 months in the chemotherapy block (HR 0.80 ; $P=0.42$ ). The most commonly reported adverse events in the erlotinib group were rash and increased aminotransferase concentrations. Another randomized, phase 3 study (OPTIMAL) [20, 21] undertaken in China also confirmed the superiority of erlotinib than first-line chemotherapy in NSCLC patients harboring EGFR mutation (13.1 vs $4 \cdot 6$ months; HR $0 \cdot 16,95 \%$ CI $0 \cdot 10-0 \cdot 26 ; p<0 \cdot 0001$ )

In the 15th World Congress of Lung Cancer, Professor $\mathrm{Wu}$ reported the results of ENSURE study in which 217 Asian patients randomly received erlotinib $(150 \mathrm{mg} / \mathrm{d})$ or gemcitabine plus cisplatin. There was no doubt that the median PFS (primary endpoint) for erlotinib was superior to the chemotherapy (11.0 and 5.5 months, respectively, $\mathrm{HR}=0.33, P<0.0001)$. Interestingly, the PFS of patients treated with erlotinib was 11.1 months and 8.3 months in the 19 exon deletion subgroups and L858R mutation in different subgroup, respectively; while it was only 4.3 months and 5.8 months in corresponding chemotherapy arm, indicating that the two types of EGFR mutations treated with erlotinib have significant benefits, and 19 exon deletion benefits more.

\section{Icotinib}

Icotinib is an oral, selective EGFR TKI made in China [22]. A randomized, phase III study (CONVINCE ) [23] proved that icotinib made significant improvements 
Table 1: Studies of first- or second-generation EGFR TKI in treated-naive patients with lung adenocarcinoma

\begin{tabular}{|c|c|c|c|c|c|c|}
\hline Study & $\begin{array}{c}\text { EGFR } \\
\text { TKI }\end{array}$ & Chemotherapy & Mutation & $\begin{array}{c}\text { Median } \\
\text { PFS } \\
\text { (months) }\end{array}$ & ORR (\%) & $\begin{array}{c}\text { Median OS } \\
\text { (months) }\end{array}$ \\
\hline IPASS & Gefitinib & Carboplatin + paclitaxel & All & 9.5 vs 6.3 & 71.2 vs 47.3 & 21.6 vs 21.9 \\
\hline WJTOG 3405 & Gefitinib & Cisplatin + docetaxel & mEtGFR & 9.2 vs 6.3 & 62.1 vs 32.2 & 36 vs 39 \\
\hline \multirow[t]{2}{*}{ First-SIGNA } & Gefitinib & Cisplatin + gemcitabine & All & 5.8 vs 6.4 & 55.4 vs 46.0 & 22.3 vs 22.9 \\
\hline & & & mEGFR subgroup & 8.0 vs 6.3 & 84.6 vs 37.5 & 27.2 vs 25.6 \\
\hline NEJ002 & Gefitinib & Carboplatin + paclitaxel & mEGFR & 10.8 vs 5.4 & 73.7 vs 30.7 & 27.7 vs 26.6 \\
\hline EURTAC & Erlotinib & Cisplatin + docetaxel & mEGFR & 9.7 vs 5.2 & 64 vs 18 & 19.3 vs 19.5 \\
\hline OPTIMAL & Erlotinib & Gemcitabine + carboplatin & mEGFR & 13.1 vs 4.6 & 83 vs 36 & NA \\
\hline \multirow[t]{2}{*}{ Lux-lung 3} & Afatinib & Cisplatin + pemetrexed & all & 11.1 vs 6.9 & 56.1 vs 22.6 & 28.2 vs 28.2 \\
\hline & & & mEGFR & 13.6 vs 6.9 & & \\
\hline Lux-lung 6 & Afatinib & Gemcitabine + cisplatin & mEGFR & 11.0 vs 5.6 & 66.9 vs 23.0 & 23.1 vs 23.5 \\
\hline
\end{tabular}

PFS $=$ Progression Free Survival.

ORR $=$ Objective Response Rate.

OS = Overall Survival.

mEGFR = EGFR mutation.

NA $=$ Not Available.

of PFS in comparison with the chemotherapy set (296 days [95\% CI 255-355] vs 219 days [189-253]; HR 0.67, $95 \%$ CI $0.49-0.90, p=0.008)$. In addition, superior tumor response rate and safety were inclined to icotinib $(64.8 \%$ vs $33.8 \%, p<0.001$; AEs in icotinib set, 104 [70.3\%] vs 121 [88.3\%], $p<0.001)$. Elevated transaminase $(29.1 \%)$, rash $(17.6 \%)$ and diarrhea $(9.5 \%)$ were the most common AEs in patients treated with icotinib. Studies about firstand second-genetation EGFR TKI as first-line treatment for EGFR mutation patients were showed in Table 1.

\section{Second-generation EGFR TKIs}

The development of second-generation EGFR TKIs is to overcome the acquired resistance which comes from the failure of first-generation EGFR TKIs. So the working mechanisms of second-generation EGFR TKIs are not exactly similar to first-generation EGFR TKIs.

\section{Afatinib}

Afatinib is a novel, orally bioavailable irreversible EGFR inhibitor, which is an aniline-quinazoline derivative with a reactive acrylamide group that can modify conserved cysteine residues by Michael addition within the catalytic domains of EGFR, HER2 and ErbB-4. By irreversible covalent bond, it blocks enzymatic activity of active ErbB receptor family members. Because the irreversible covalent binding can inhibit the kinase activity until the synthesis of new receptors, the action time of afatinib may longer than reversible EGFR TKIs [7].

LUX-Lung 3 [11] trial was a global, randomized study which evaluated the efficacy and safety between afatinib and chemotherapy as a first-line treatment in patients with proven EGFR mutation and lung adenocarcinoma histologically. Eligible patients $(n=345)$ were randomly allocated in 2:1 ratio to either afatinib arm or pemetrexed plus cisplatin [24]. Generally, afatinib showed significant prolongation of median PFS than chemotherapy and median PFS was 11.1 and 6.9 months, respectively (HR: 0.58 ; 95\% CI: $0.43-0.78$; $p=0.0004$ ). In addition, the median PFS was 13.6 months for patients treated with afatinib in comparison with 6.9 months for patients treated with chemotherapy in Del 19/L858R subgroup (HR: 0.47 ; 95\% CI: 0.34-0.65; $p<0.0001)$. Furthermore, the RR was also significantly higher in afatinib group compared with in chemotherapy group (56.1\% and $22.6 \%$, respectively).

The largest prospective phase III study (LUX-Lung 6) [12] was undertaken in EGFR mutation-positive lung cancer. Researchers randomized 364 patients to receive afatinib or gemcitabine plus cisplatinin in a 2:1 ratio. Compared with chemotherapy, in patients with common EGFR mutations (Del19/L858R), mPFS was significantly prolonged with afatinib (11.0 vs 5.6 months; HR: 0.28; $p<0.0001)$. The afatinib group also achieved higher objective response (66.9 vs $23.0 \% ; p<0.0001)$ and disease control rates (92.6 vs $76.2 \% ; p<0.0001$ ) .

A combination analysis of LUX-lung3 and LUXlung6 $[13,25]$ had proved that 19 exon deletion tumours were different from L858R mutations tumours, and the former may be better: median OS was better in the 19 exon deletion compared with the chemotherapy group no matter in LUX-Lung 3 or LUX-Lung 6, while no statistically significant difference was observed in the L858R mutations group. The most common treatment-related AEs were diarrhea, rash/acne, stomatitis and nail effects. 
Compared with first-generation EGFR-TKIs, afatinib is the only one to exhibit an OS benefit in patients harboring 19 exon deletion instead of L858R mutations than chemotherapy. This benefit may be attributed to the following reasons: distinct biological properties of 19 exon deletion and L858R mutations, the differences existing in reversible EGFR TKI and the irreversible ERBB family blocker afatinib, or both. The above results suggested that clinicians should make a difference between patients harbouring 19 exon deletion L858R mutations in the stratified analysis of future clinical trials. But in current state, all those patients carrying EGFR mutations still should be treated with EGFR inhibitors as first-line no matter first-generation or afatinib based on better PFS.

\section{Dacomitinib}

Dacomitinib as an pan-HER TKI is to target EGFR, ErbB2 and ErbB4 kinase, and it domains of the EGFR signaling pathway by irreversibly bind the ATP [26, 27]. It is published that the PFS (the primary endpoint) demonstrated a statistical improvement for dacomitinib over erlotinib as second-line (median 2.8 vs 1.9 months, $p=0.012$ ) [28]. In a phase II study, dacomitinib was evaluated as first-line treatment for patients with either EGFR mutation or less than a 10 pack-year smoking history. Interim results demonstrated that the primary endpoint of PFS at 4 months was $96 \%$ in overall population. In addition, the patients with EGFR mutationpositive gained an objective responses of $74 \%$ (95\% CI: 59-86) [29].

\section{Third-generation EGFR TKIs}

Nowadays, several EGFR TKIs such as gefitinib, erlotinib and afatinib are approved worldwide for the treatment of NSCLC harbouring EGFR mutations. These target drugs can improve PFS, ORR and quality of life in comparison with conventional chemotherapy in first-line setting. Unfortunately, all patients treated with gefitinib, erlotinib or afatinib will unavoidably generate resistance to previous drug [30]. To a large extent, either acquired or intrinsic resistance can reduce the efficacy of EGFR TKIs [31]. These published mechanisms include the development of T790M mutation, CMET amplification, HER2 amplification, histological transformation to smallcell histology, and so on [32, 33]. Among them, the most important mechanism of acquired resistance is the EGFR T790M mutation. It was reported that occurrence frequency of T790M mutation was from $49 \%$ to $63 \%$ after rebiopsies [34-36]. The competitive combination ability of first-generation and second-generation TKIs has been reduced by $\mathrm{T} 790 \mathrm{M}$ mutation through changing the affinity of EGFR for ATP [31, 37]. To overcome this new difficulty, different third-generation EGFRmutant selective TKIs, such as osimertinib, rociletinib and olmutinib, came into being (Table 2) [38, 39]. These agents are specifically designed to inhibit EGFR T790M without wild-type EGFR, which structurally different from first-generation and second-generation inhibitors [40, 41].

\section{Osimertinib (taggriso, AZD9291)}

Osimertinib could irreversibly and selectively inhibit both T790M mutation-positive EGFR and sensitizing EGFR [42, 43]. In recent decades, a global phase 1 trial (AURA 1) [44] reported that the ORR of osimertinib was amazingly up to $51 \%$ in all patients (95\% CI: 45\%-58\%). The ORR was 61\% (95\% CI: $52 \%-70 \%)$ and $21 \%(95 \%$ CI: $12 \%-34 \%)$ in patients with EGFR T790M mutations and without the EGFR T790M mutations, respectively. The AURA2 Phase I/II study [44] convinced that patients with activating EGFR mutations and T790M mutations can benefit from an $80 \mathrm{mg}$ once-daily dose of osimertinib at second-line treatment. The final ORR was $71 \%$ and animmature PFS was 8.6 months. Recently, the New England Journal published preliminary results of the AURA3 study [45] in which osimertinib significantly improved the mPFS compared with chemotherapy for patients carrying EGFR T790M and previously treated with EGFR TKIs (10.1 vs 4.4 months $\mathrm{HR}=0.3$, 95\% CI $0.23-0.41, P<0.001)$. Besides, objective response rate of $71 \%$ also supports osimertinib. In addition, two phase I expansion cohorts were designed to assess that osimertinib was used for first-line treatment for EGFR mutation-positive advanced NSCLC. In this study, 60 treatment-naïve patients received two dose levels (80 mg; $160 \mathrm{mg})$. The end ORR was 77\% (95\% CI 64, 87) and the $160 \mathrm{mg}$ cohort got the higher ORR than the $80 \mathrm{mg}$ cohort (87\% versus 67\%). The mPFS was 19.3 months (95\% CI 13.7, NC) among all patients, and the mPFS of $80 \mathrm{mg}$ cohort didn't reach $(95 \%$ CI $12.3, \mathrm{NC})$ while the other cohort was 19.3 months $(95 \%$ CI $11.1,19.3)$ at the time cut-off. Also, the disease control rate reached up to 97\% (95\% CI 88.5, 99.6). [46] The most common adverse events of osimertinib were diarrhea, rash, nausea, and decreased appetite.

\section{CO1686 (rociletinib)}

Similar to osimertinib, CO1686 is considered as another prospective third-generation irreversible EGFR TKI [41]. In primary phase I/II trial, 130 patients (but the study ultimately included 612 patients) were randomly assigned to take the free-base form of rociletinib or the hydrogen bromide salt form. The update data showed median PFS of the T790M-positive set and T790M negative was 6.1 months (95\% CI, 4.2 to 9.6$)$ and 1.8 months (95\% CI, 1.2 to 3.0$)$, respectively. The final response rate was $45 \%$ in patients with $\mathrm{T} 790 \mathrm{M}+$. The common adverse events were nausea, fatigue, diarrhea, and grade 3 hyperglycemia. The updated data showed the response rate of rociletinib from initial $59 \%$ to a confirmed $45 \%$ among patients with $\mathrm{T} 790 \mathrm{M}+$. The researchers attributed this reduction to a fact that more than half patients had performed only once imaging evaluation 
Table 2: The clinical studies for third-generation EGFR TKI

\begin{tabular}{|c|c|c|c|c|}
\hline & Study & Number $^{\mathrm{a}}$ & ORR & PFS (months) \\
\hline AZD9291 & $\begin{array}{l}\text { AURA1 } \\
\text { I }\end{array}$ & 253 & $\begin{array}{c}51 \% \mathrm{~T} 790 \mathrm{~m}+60 \% \\
\text { T790 m- } 28 \%\end{array}$ & NA \\
\hline AZD9291 & $\begin{array}{c}\text { AURA2 } \\
\text { I/II }\end{array}$ & $472 / 210$ & $71 \%$ & 8.6 \\
\hline AZD9291 & $\begin{array}{c}\text { AURA3 } \\
\text { tIII }\end{array}$ & $419 / 279$ & $71 \%$ & 10.1 \\
\hline CO1686 & I/II & $612 / 69$ & $\begin{array}{l}\text { T790 m+ }+45 \% \\
\text { T790 m- } 17 \%\end{array}$ & 6.1 \\
\hline HM61713 & $\mathrm{I} / \mathrm{II}$ & 71 & $56 \%$ & 7.0 \\
\hline
\end{tabular}

${ }^{a}$ Number of patients assigned/number of patients treated by third-generation EGFR TKI.

ORR $=$ Objective Response Rate.

PFS $=$ Progression Free Survival.

$\mathrm{NA}=$ Not Available.

at data cutoff. Besides, the optimal dose of rociletinib, $500 \mathrm{mg}$ or $625 \mathrm{mg}$ bid, is still not clear [38, 47]. So it is necessary to carry out more clinical studies to assess rociletinib before large-scale applications.

\section{HM61713 (olmutinib)}

HM61713 is a new, oral inhibitor can target selectively either activating EGFR mutations or T790Mdisease, but except EGFR wild-type. An ongoing phase I/II trial of HM61713 was performed in advanced NSCLC patients who had failed in previous treatment. The preliminary data reported that median PFS was 7.0 months (95\% CI 5.5-8.3) and there were 26 (34\%) patients still being treated at data cut-off. Diarrhea, rash, pruritus, and nausea were most frequent adverse reactions. Among 71 patients evaluated for remission, 40 (56\%) reached an objective response by researchers examination (31 [44\%] confirmed) and median duration of response was 8.3 months (range 5.6-NE). It is encouraging that disease control rate reached $90 \%$ [48].

\section{AC0010}

AC0010 is an irreversible EGFR inhibitor based on pyrrolopyrimidine, which is structurally different from previously published pyrimidine-based irreversible EGFR inhibitors, such as osimertinib and rociletinib. In a xenograftmodel, AC0010 caused tumors complete remission more than 143 days without weight loss in EGFR-active and T790M mutations. Metabolite detection results demonstrated that AC0010 didn't target wild-type EGFR and no off-target effects occurred. The safe dose of AC0010 range from 50 to $550 \mathrm{mg}$ daily in NSCLC patients, and no severe adverse events were reported. Besides, the investigators observed the objective responses happen to patients with EGFR T790M mutation [49].

Briefly, the third generation EGFR TKIs seem to bring new hopes for patients who progressed after treated with EGFR TKIs. And the T790M mutation- positive patients will be obtained greater efficacy than T790M mutation-negative patients. Recently, more and more clinical trials put three-generation EGFR TKIs into first-line treatment for NSCLC. Ongoing trials will explore whether the patient with intrinsic resistance NSCLC can benefit from the third-generation EGFR TKIs $[50,51]$. Regrettably, there are new resistance mechanism to challenge third-generation EGFR TKIs, such as HER2 amplification, CMET amplification, KRAS G12S mutation, histological transformation, and EGFR L718Q mutation. Among these, C797S mutation was considered to be the biggest difficulty to osimertinib $[52,53]$. Therefore, it is urged to develop new agents to target this particular mutant.

\section{Fourth-generation EGFR TKIs}

The EGFR C797S mutation, occurring in 32\% of patients, can keep irreversible EGFR TKIs from covalent binding [54-56]. In order to overcome the new mutation, the fourth-generation EGFR-TKIs appeared.

\section{EAI045}

EAI045 is the first allosteric inhibitor that targets T790M and C797S EGFR mutants. Interestingly, it is only when combined with cetuximab that EAI045 is working. The investigators found that EAI045 was markedly more active in dimerization-defective EGFR mutants. EAI045 apparently inhibited the proliferation of $\mathrm{Ba} / \mathrm{F} 3$ cells bearing L858R/T790M mutation when combined with cetuximab that can block EGFR dimerization through preventing EGF ligand binding [57].

The emergence of EAI045 has brought a glimmer of hope for NSCLC patients, but the current studies are only in a preclinical stage. Besides, because the C797S mutation is not the only mechanism for resistance to third-generation EGFR TKIs, EAI045 did not completely overcome the problems of those resistances. So there is still a long way to go for fourth-generation EGFR TKIs. 
Table 3: Randomized studies of comparing the EGFR TKI in advanced NSCLC with EGFR mutations patients

\begin{tabular}{cccccc}
\hline Study & EGFR TKI & EGFR TKI & $\begin{array}{c}\text { Median PFS } \\
\text { (months) }\end{array}$ & ORR (\%) & $\begin{array}{c}\text { Median OS } \\
\text { (months) }\end{array}$ \\
\hline $\begin{array}{c}\text { CTONG } \\
0901\end{array}$ & Gefitinib & Erlotinib & 10.4 vs 13.0 & 52.3 vs 56.3 & 20.1 vs 22.9 \\
$\begin{array}{c}\text { LUX-Lung 7 } \\
\text { ARCHER 1050 }\end{array}$ & Afatinib & Gefitinib & 11.0 vs 10.9 & 70 vs 56 & 27.9 vs 24.5 \\
NCT01774721) & Dacomitinib & Gefitinib & NA & NA & NA \\
NCT02296125 & AZD9291 & $\begin{array}{c}\text { Gefitinib or } \\
\text { Erlotinib }\end{array}$ & NA & NA & NA \\
NCT02186301 & Rociletinib & Erlotinib & NA & NA & NA \\
\hline
\end{tabular}

PFS $=$ Progression Free Survival.

ORR $=$ Objective Response Rate.

OS $=$ Overall Survival.

$\mathrm{NA}=$ Not Available.

\section{EGFR TKI versus EGFR TKI}

After more than decades of research, the market has appeared several generations of EGFR-TKI. At present, the most specific and urgent problem is to choose the right EGFR-TKI to maximize clinical benefits for patients, which is also the significance of trials to compare with different drugs. As shown in Table 3.

\section{Gefitinib VS Erlotinib}

CTONG0901 trial [58] was the primary prospective head-to-head study to compare the first-generation EGFR-TKIs in advanced NSCLC with EGFR mutations patients all over the world. 256 eligible patients were assigned to randomly receive erlotinib or gefitinib until disease progression or unacceptable toxicity. However, the primary end point didn't reached (mPFS gefitinib vs erlotinib, 10.4 VS $13 \mathrm{~m}$, HR $0.81, P=0.108$ ). Besides, regardless of the EGFR exon19 or exon 21 mutations, erlotinib did not receive a significantly better efficiency and survival benefits than gefitinib. Both of them had similar toxicity. Meanwhile, no matter erlotinib arm or gefitinib arm, patients with EGFR exon19 had significantly better RR and OS than those with exon21 mutations.

\section{Afatinib VS Gefitinib}

LUX Lung-7 [59] was the first randomized study that head-to-head to compare first-generation and secondgeneration EGFR-TKI. In this study, 319 NSCLC patients with common EGFR mutation-positive were randomized to either afatinib or gefitinib in first-line. Finally, afatinib significantly improved PFS (11.0 vs. 10.9 months, $P=0.017)$ and TTF (13.7 vs. 11.5 months, $P=0.0073)$ of patients than gefitinib. Both the risk of progression and treatment failure was reduced by $27 \%$ and the results were consistent across subgroups including EGFR mutational subgroups. AEs in both groups were consistent with previous experience (drug-related $\mathrm{AE}$, afatinib $=98.8 \%$, gefitinib $=100.0 \%$ ), and were manageable leading to equally low rates of treatment discontinuation $(6.3 \%$ for both treatment groups). After a median follow-up of 42.6 months, the median OS was no statistically significant difference between afatinib group and gefitinib group (median OS, 27.9 versus 24.5 months; HR, 0.86; 95\% CI $0.66-1.12 ; P=0.2580$ ) [60].

For real-world clinical practice and treatment guidelines, the 0.1-month PFS benefit do not have too much influential. However, this result may indicate afatinib has broader and longer-lasting inhibitory effect and is capable to extend the time of response in comparison with gefitinib. For instance, afatinib can inhibit signal transduction of ErbB2 and ErbB3, which are associated with acquired tolerance to first-generation EGFR TKIs. Additionally, previous study reflected that afatinib is effective to target EGFR with the T790M mutation, and preceding studies have demonstrated that afatinib has potential efficacy to benefit patients with progression after first-generation TKIs [59].

\section{Dacomitinib VS Gefitinib}

Nowadays, a phase 3 study to evaluate dacomitinib versus gefitinib at first-line treatment for advanced NSCLC is underway(ARCHER 1050). Investigators randomized 440 patients to dacomitinib (45 mg daily) or gefitinib. (250 mg daily) in a 1:1 ratio. This study is expected to yield preliminary results in 2017. (ClinicalTrials.gov Identifier: NCT01774721).

\section{Osimertinib VS Gefitinib or Erlotinib}

A phased III study is underway to compare osimertinib with gefitinib or erlotinib as first-line treatment for patients with locally advanced or metastatic NSCLC. PFS is the primary end point, and assessment of PFS is the secondary end points which based on T790M 
mutation status before treatment and the common EGFR mutation (exon 19 deletion or L858R) tested by circulating tumor DNA. We are expecting early clinical results of this experiment. (NCT02296125).

\section{Combined therapy}

EGFR TKI monotherapy brought obvious but limit benefits for NSCLC with EGFR mutations, so several clinical trials of combined therapy based on EGFR TKI are being investigated, and many of these have achieved satisfactory results.

\section{EGFR TKI plus chemotherapy}

NEJ005/TCOG0902 [61] is the earliest randomized study to evaluate the association efficacy and safety of EGFR-TKI and chemotherapy in the EGFR mutationpositive patients. The investigators randomized 80 untreated NSCLC patients with EGFR mutation to either a concurrent or a sequential treatment plan with gefitinib and classic chemotherapy(carboplatin/ pemetrexed). The final results showed that the mPFS was 18.3 months $(n=41)$ and 15.3 months $(n=39)$ in the concurrent and sequential alternating regimen groups, respectively[HR $0.71(0.42-1.20), P=0.20]$. Preliminary results reported that the median OS got a significant result: 41.9 versus 30.7 months, respectively [HR 0.51 (0.26-0.99); $P=0.042$ ]. Besides, both groups got similar response rates $(87.8 \%$ and $84.6 \%)$. The adverse events commonly observed were reversible, and no one fatal interstitial lung disease appeared. Before this final analysis, the new phase III NEJ009 (UMIN000006340) study has begun and now is no longer recruiting, and the purpose of this trial is to compare standard gefitinib with or without chemotherapy in the EGFR-mutated individuals.

FAST-ACT II [62] is the first randomized phase 3 study to demonstrate the efficacy of intercalated regimen of chemotherapy in combination with an EGFR inhibitor for patients with advanced NSCLC. Patients untreated previously with advanced non-small cell lung cancer randomly received six cycles of chemotherapy cooperation with intercalated erlotinib or placebo orally every 4 weeks. Based on the final results, it can be found that PFS was significantly better in the combined erlotinib arms than placebo arms ( mPFS $7 \cdot 6$ vs $6 \cdot 0$ months, HR 0.57 [0.47-0.69]; $p<0.0001)$. In addition, the median OS also supported the former (18.3 months and 15.2 months, respectively; HR 0.79 [0.64-0.99]; $p=0 \cdot 0420)$. Besides, in patients with EGFR mutationpositive, the benefits of treatment were significant difference (mPFS 16.8 vs 6.9 months, HR $0 \cdot 25$ [0.16$0 \cdot 39$ ]; $p<0 \cdot 0001 ; \operatorname{mOS} 31 \cdot 4$ months [22.2-undefined] vs 20.6 months [14.2-26.9], HR 0.48 [0.27-0.84]; $p$ $=0.0092$ ). In terms of safety, slightly more patients in placebo group were reported to have serious adverse events (76 (34\%) of 222 versus $69(31 \%)$ of 226 ), and the commonly observed grade 3 or greater adverse events were neutropenia, thrombocytopenia, and anaemia.

A randomized phase II trial (JMIT) [63] investigated gefitinib combined with pemetrexed and gefitinib alone as first-line therapy for advanced nonsquamous NSCLC with activating EGFR mutations. Investigator randomized 195 Asian patients with EGFR mutations to pemetrexed plus gefitinib or gefitinib alone in 2:1 ratio. The median PFS was 15.8 months in $\mathrm{P}+\mathrm{G}$ set, which was significantly longer than 10.9 months in gefitinib set (adjusted HR, 0.68; 95\% CI, 0.48 to 0.96 ; one-sided $P=.014$; two-sided $P=.029$ ). The results of progressive disease and duration of response were consistent with mPFS (median, $16.2 \mathrm{v} 10.9$ months, respectively; HR, 0.66 ; $95 \% \mathrm{CI}, 0.47$ to 0.93 ;median, 15.4 v 11.3 months, respectively; HR, 0.74; 95\% CI, 0.50 to 1.08$)$. Moreover, ORR were similar and the overall survival data are immature between two groups. In safety, the combination group had more grade 3 or worse AEs, but toxicities were common and manageable.

\section{EGFR TKI plus anti-angiogenic drugs}

Admittedly, angiogenesis is necessary for tumor development and invasion, so a high microvessel density has been identified as a predictive factor of metastasis [64]. VEGF is regarded as the most potent regulator of angiogenesis and is the target of NSCLC verification $[65,66]$. The VEGF and EGFR pathways are known to be interrelated. Activation of EGFR can increase VEGF expression by its ligands at the cellular level [64, 67]. Similarly, EGFR inhibition can make VEGF downregulated through both hypoxia-inducible factor- $\alpha-$ dependent and independent mechanisms [68-74].

Some preclinical studies intimated the antiangiogenic monoclonal antibody bevacizumab could enhance antitumor activity when used in combination with EGFR-TKI in NSCLC cells carrying an EGFR mutation, especially in cells that express high levels of VEGF [64].

In several trials, combining the anti-angiogenic monoclonal antibody bevacizumab with EGFR-TKI has exhibited additional efficacy in unselected NSCLC patients $[75,76]$. In a phase 3 BeTa study that compared the combination of erlotinib and bevacizumab with erlotinib alone as second-line strategy for NSCLC. The subgroup analysis of EGFR mutation-positive participants reported that mPFS in the combination group was substantially longer than monotherapy group $(17 \cdot 1$ months vs 9.7 months). [76, 77] According to this study, Takashi Seto'el undertook an randomized, phase 2 trial (JO25567) $[64,78]$ to examine the efficacy and safety of erlotinib with or without bevacizumab as first-line therapy for patients with EGFR mutation NSCLC. Finally, this study presented that the PFS of combination therapy was longer than that of erlotinib monotherapy (16.0 months and 9.7 months, hazard ratio $0 \cdot 54,95 \%$ CI $0 \cdot 36-0 \cdot 79$; 
$p=0.0015)$. In addition, the incidence of serious adverse events was equivalent in both groups (18 [24\%] patients in two drug group and 19 [25\%] patients in single drug group). Grade 3 or worse AEs observed were rash, hypertension, and proteinuria.

The results of BELIEF study have exhibited in the 2015 European Cancer Congress,and it showed that the ORR (76.1\%) and PFS (13.8 months; 95\% CI: 10.3-21.3) of combination with bevacizumab and erlotinib were significantly improved independent of T790M status. The 1-year PFS of T790M mutation positive was $72.4 \%$ and median PFS was 16.0 months (95\% CI: 13.1-NE). By contrast, the data were $49.4 \%$ and 10.5 months $(95 \%$ CI: 9.2-16.2) in patients without T790M mutation. The safety trial of osimertinib combined with bevacizumab for advanced NSCLC with EGFR mutations is recruiting. (NCT02803203).

The above studies show that the combination of bevacizumab and EGFR TKIs may be a promising pattern for EGFR mutant patients, even for those with intrinsic resistance to EGFR TKIs. The combination mechanism of bevacizumab may enhance the anti-tumor activity of EGFR TKIs and perhaps increase intratumoral concentration of EGFR TKIs to partially reverse intrinsic resistance [79].

\section{EGFR TKI plus immunotherapy}

The PD-1/PD-L1 checkpoint inhibitors have brought an promising prospect in advanced NSCLC, such as nivolumab and pembrolizumab [80-82]. Based on this reason, they have been already recommended to apply to clinical treatment in advanced NSCLC.

High expression of PD-L1 is an efficacy predictor of PD-L1 inhibitors and prognostic marker in tumor tissues in non-squamous NSCLC [81]. Interestingly, the expression of PD-L1 is associated with EGFR mutation. It is reported that the NSCLC cell lines with activating EGFR mutations expressed higher PD-L1. That is to say, EGFR mutations contribute to the up-regulation of PD-L1 expression [83-87]. As part of TATTON study, the combined application of osimertinib and durvalumb in NSCLC patients harboring EGFR mutation was investigated. 11 EGFR TKI-naive patients (Part B, dose expansion) were treated with $80 \mathrm{mg}$ osimertinib plus $3 \mathrm{mg} / \mathrm{kg}$ or $10 \mathrm{mg} / \mathrm{kg}$ durvalumab every fortnight. The results showed that ORR was $70 \%$. However, this combination was associated with high incidence of interstitial lung disease (ILD), which was noted in 64\% [7/11]. So far, the underlying mechanism associated with high incidence of ILD is still unknown and being investigated. Thus, further enrollment of this arm has been permanently suspended [88]. Another combination of gefitinib plus durvalumab is being investigated in ongoing phase Ib study [89]. In dose-expansion phase, 10 EGFR TKI-naive patients were treated with concurrent durvalumab $(10 \mathrm{mg} / \mathrm{kg}$ every fortnight) and gefitinib (250 mg qd) in arm 1 or treated with gefitinib monotherapy lead-in for 4 weeks followed by concurrent durvalumab plus gefitinib in arm 2 , respectively. The ORR was $77.8 \%$ in the former, and $80.0 \%$ in the latter, respectively. And the more common treatment-related AEs were demonstrated in $80 \%$ and $60 \%$ for each arm. However, the adverse of grade 3/4 were alanine aminotransferase (ALT) elevation (70\% in arm $1 \mathrm{vs.} 60 \%$ in arm 2) and aspartate aminotransferase (AST) elevation (40\% in arm 1 vs. $50 \%$ in arm 2) in both arms. Currently, there are several clinical studies in progress now and some important data will soon be published about the combination of EGFR TKIs and immunotherapy, such as GEFTREM, NCT02630186 and NCT02496663.

Combined therapy based on EGFR TKI with better efficacy and controllable adverse effects (Table 4) could be applied to clinical treatment as a potentially valuable treatment regimen. However, not all combined therapy models can be applied. Clinicians should choose the most appropriate treatment for patients based on patients' performance status, economic status, personal wishes, and clinical experience.

\section{Future challenges}

\section{Intratumor heterogeneity}

Although EGFR TKI can benefit patients with EGFR mutation, drug resistance is still unavoidable, Intratumor heterogeneity may be the lead culprit of cancer resistance, and introduce significant challenges in designing effective treatment strategies. It is reported that the cancer stem cell model and the clonal evolution model were served to explain the heterogeneity of tumour cells [90-92]. We believe that these patterns are coexistent, and they are both conducive to heterogeneity in different stages, such as tumour growth and disease aggression. We found that the use of cytotoxic drugs usually lead original tumor shrinkage. This means the disruption of the original nonresistant subclonal populations in heterogeneous tumors, leaving only resistant clones. After a period of time, these resistant tumour populations could replicate and develop a new tumour by the branching evolution mechanism. The new tumour may be heterogeneous and insensitive to the used therapy, even more aggressive. TRACERx study showed that intratumor heterogeneity can increase the risk of recurrence of tumor and death of patients by chromosome instability. As a result, chromosome instability may be a potential prognostic predictor [93-94]. And up to now, there are still no effective predictors to evaluate treatment efficacy and progress tendency. Therefore, the more understanding about heterogeneity can provide a deeper recognization to the occurrence and development of tumor. Conversely, it is important to guide precision medicine strategies that integrate knowledge of heterogeneity to achieve higher efficacy. 
Table 4: Adverse effects of combined therapy in major clinical trials

\begin{tabular}{|c|c|c|c|c|c|c|c|c|c|c|}
\hline \multirow{2}{*}{ Study } & Neutropenia & Anemia & Thrombocytopenia & Diarrhea & Rash & Paronychia & Stomatitis & $\begin{array}{c}\text { AST/ALT } \\
\text { elevation }\end{array}$ & LD & Hypertension \\
\hline & $\begin{array}{c}\geq \text { Grade3 } \\
(\%)\end{array}$ & $\begin{array}{c}\geq \text { Grade3 } \\
(\%)\end{array}$ & $\begin{array}{c}\geq \text { Grade3 } \\
(\%)\end{array}$ & $\begin{array}{c}\geq \text { Grade3 } \\
(\%)\end{array}$ & $\begin{array}{c}\geq \text { Grade3 } \\
(\%)\end{array}$ & $\begin{array}{c}\geq \text { Grade3 } \\
(\%)\end{array}$ & $\begin{array}{c}\geq \text { Grade3 } \\
(\%)\end{array}$ & $\begin{array}{c}\geq \text { Grade3 } \\
(\%)\end{array}$ & $\begin{array}{c}\geq \text { Grade3 } \\
(\%)\end{array}$ & $\begin{array}{c}\geq \text { Grade3 } \\
(\%)\end{array}$ \\
\hline \multirow[t]{2}{*}{ NEJ $005^{1,2}$} & 48.8 & 34.1 & 41.5 & 9.8 & 2.4 & 2.4 & 4.9 & 9.8 & 0.0 & NA \\
\hline & 46.2 & 12.8 & 28.2 & 0.0 & 0.0 & 2.6 & 0.0 & 20.5 & NAa & NA \\
\hline FASTACT- $2^{3}$ & 29 & 11 & 14 & 1 & 5 & NA & 0.0 & NA & $\mathrm{NAb}$ & NA \\
\hline $\mathrm{JMIT}^{4}$ & 5 & 3 & NA & 1 & NA & NA & 4 & 22 & 1 & NA \\
\hline $\mathrm{JO} 25567^{5}$ & NA & NA & NA & 1 & 25 & 3 & 1 & NAc & 0 & 60 \\
\hline 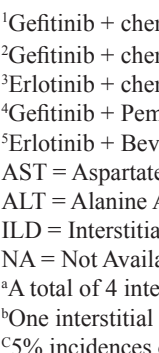 & $\begin{array}{l}\text { herapy Concurre } \\
\text { herapy Sequenti } \\
\text { herapy. } \\
\text { exed. } \\
\text { zumab. } \\
\text { ninotransferase. } \\
\text { notransferaseT. } \\
\text { ang Disease. } \\
\text { tial lung diseases } \\
\text { g disease event o }\end{array}$ & $\begin{array}{l}\text { regimen. } \\
\text { alternating re }\end{array}$ & occurred (grade 1 an & 2 events in & concurre & and grade 2 & 4 events & he sequer & alternatir & gimen group) \\
\hline
\end{tabular}

The detection of tumour heterogeneity and resistance mechanisms after EGFR TKI therapy largely relied on tumor biopsies. TRACERx [93] study found that $86 \%$ tumor regions carried only a single branch of the phylogenetic tree in a median of 5 per tumor (range, 2 to 15 ). If using a single diagnostic biopsy sample, other information about the tumor would be missed, and lead to a mixed response in subsequent treatment. Therefore, multi-point sampling, dynamic monitoring can be fully reflected evolution process of tumor from early stages. It was reported that ctDNA can prompt the recurrence time of tumor ahead 70 days, than the traditional imaging examination [95]. A study that compares 1,033 tissue samples with 803 plasma samples from the same patients found that the concordance between ctDNA analysis and tissue at diagnosis was $94.3 \%$ in identifying EGFR mutations, with $65.7 \%$ sensitivity and $99.8 \%$ specificity [96]. Besides, the T790M mutation could be also detected effectively through using plasma DNA [97-99]. However, a study about early stage lung cancer showed that histological subtype influenced ctDNA detection: $19 \%(11 / 58)$ of lung adenocarcinomas were ctDNA positive, compared with $97 \%$ (30/31) of lung squamous cell carcinomas. Furthermore, driver event in EGFR was not associated with ctDNA detection within lung adenocarcinoma [95]. It indicates that ctDNA still has huge challenges when facing lung adenocarcinoma with EGFR mutation. In addition,, aurine-based test, RT-PCR and digital PCR assays are also in progress. Using plasmabased molecular testing to monitor disease status and clinical response to therapy may help to make decisions more rapidly.

\section{Unknown EGFR mutations}

It is known that all patients with mutant EGFR will ultimately generate resistance to EGFR TKI therapy after first or secondary generation EGFR TKI. Drugs targeting these mutations have been published, such as thirdgeneration EGFR TKIs. Now, four-generation EGFR TKIs targeting three-generation drug resistance drugs are also on the road. Then what? Because the mechanism of drug resistance is not yet clear, targeted therapy of lung cancer would fall into the dilemma of drug resistance again. If the three-generation EGFR TKIs were applied to the front line, we don't know whether it will produce similar to the effect of "multiple drug-resistant bacteria", making the follow-up treatment of NSCLC insensitive. Therefore, in order to determine more unknown mutations, the relevant research should closely monitor the response to subsequent treatment of tumor.

\section{Detecting technologies in ctDNA}

CtDNA detection has been commonly used in clinical practice to detect EGFR mutation state besides tissue sampling [100-101]. Thus, for the accuracy and convenience of clinical application, it is necessary to have a higher level technique for detection in ctDNA. The more popular detection strategies for plasma EGFR analysis are amplification refractory mutation system (ARMS), droplet digital PCR (ddPCR) and nextgeneration sequencing (NGS)-based methods [102]. Among them, ADx-ARMS (ADx ${ }^{\circledR}$ EGFR 29 Mutations Detection Kit) and Cobas-ARMS (cobas ${ }^{\circledR}$ EGFR Mutation Test v2) have been approved for clinical use by the China Federal Drug Administration (CFDA) and the U. S. Food and Drug Administration (FDA) for the detection of EGFR mutations in plasma respectively. By comparison, ddPCR and NGS-based methods are extensively applied in study because of their quantitative advantage. However, the lasted study confirmed the capacity of four major detection systems to detect EGFR mutations in ctDNA from a small sample and the results 
indicated that three methods except ADx-ARMS all showed better sensitivity. When the allele frequency of EGFR mutations is more than $1 \%$ in plasma and tissue samples, ADx-ARMS may be a better choice as a qualitative detection by comparison [102]. In general, Firefly NGS platform may be the most sensitive technique for EGFR mutational profiling considering the sensitivity, specificity, mutation information, and the clinical efficacy of EGFR [102]. However, because the sample size is too small, there will be a larger prospective study to validate those findings. What we needed is a more accurate, less invasive diagnostic approach, which provides us the right directions in future researches.

\section{CONFLICTS OF INTEREST}

None.

\section{FUNDING}

This work was supported by The National Major Scientific and Technological Special Project for "Significant New Drugs Development" during the Thirteenth Five-year Plan Period of China (2016ZX09101005).

\section{REFERENCES}

1. Siegel RL, Miller KD, Jemal A. Cancer Statistics, 2017. CA Cancer J Clin. 2017; 67:7-30.

2. Schiller JH, Harrington D, Belani CP, Langer C, Sandler A, Krook J, Zhu J, Johnson DH. Comparison of four chemotherapy regimens for advanced non-small-cell lung cancer. N Engl J Med. 2002; 346:92-8.

3. Tan CS, Gilligan D, Pacey S. Treatment approaches for EGFR-inhibitor-resistant patients with non-small-cell lung cancer. Lancet Oncol. 2015; 16:e447-59.

4. Lynch TJ, Bell DW, Sordella R, Gurubhagavatula S, Okimoto RA, Brannigan BW, Harris PL, Haserlat SM, Supko JG, Haluska FG, Louis DN, Christiani DC, Settleman J, et al. Activating mutations in the epidermal growth factor receptor underlying responsiveness of non-small-cell lung cancer to gefitinib. N Engl J Med. 2004; 350:2129-39.

5. Paez JG, Jänne PA, Lee JC, Tracy S, Greulich H, Gabriel S, Herman P, Kaye FJ, Lindeman N, Boggon TJ, Naoki K, Sasaki H, Fujii Y, et al. EGFR mutations in lung cancer: correlation with clinical response to gefitinib therapy. Science. 2004; 304:1497-500.

6. Morgillo F, Della Corte CM, Fasano M, Ciardiello F. Mechanisms of resistance to EGFR-targeted drugs: lung cancer. ESMO Open. 2016; 1:e000060.

7. Jain P, Khanal R, Sharma A, Yan F, Sharma N. Afatinib and lung cancer. Expert Rev Anticancer Ther. 2014; 14:1391-406.

8. Rosell R, Moran T, Queralt C, Porta R, Cardenal F, Camps C, Majem M, Lopez-Vivanco G, Isla D, Provencio M, Insa
A, Massuti B, Gonzalez-Larriba JL, et al. Screening for epidermal growth factor receptor mutations in lung cancer. $\mathrm{N}$ Engl J Med. 2009; 361:958-67.

9. Tartarone A, Lerose R. Clinical approaches to treat patients with non-small cell lung cancer and epidermal growth factor receptor tyrosine kinase inhibitor acquired resistance. Ther Adv Respir Dis. 2015; 9:242-50.

10. Hirsch FR, Bunn PA Jr. EGFR testing in lung cancer is ready for prime time. Lancet Oncol. 2009; 10:432-3.

11. Sequist LV, Yang JC, Yamamoto N, O’Byrne K, Hirsh V, Mok T, Geater SL, Orlov S, Tsai CM, Boyer M, Su WC, Bennouna J, Kato T, et al. Phase III study of afatinib or cisplatin plus pemetrexed in patients with metastatic lung adenocarcinoma with EGFR mutations. J Clin Oncol. 2013; 31:3327-34.

12. Wu YL, Zhou C, Hu CP, Feng J, Lu S, Huang Y, Li W, Hou M, Shi JH, Lee KY, Xu CR, Massey D, Kim M, et al. Afatinib versus cisplatin plus gemcitabine for first-line treatment of Asian patients with advanced non-small-cell lung cancer harbouring EGFR mutations (LUX-Lung 6): an open-label, randomised phase 3 trial. Lancet Oncol. 2014; 15:213-22.

13. Yang JC, Wu YL, Schuler M, Sebastian M, Popat S, Yamamoto N, Zhou C, Hu CP, O’Byrne K, Feng J, Lu S, Huang Y, Geater SL, et al. Afatinib versus cisplatinbased chemotherapy for EGFR mutation-positive lung adenocarcinoma (LUX-Lung 3 and LUX-Lung 6): analysis of overall survival data from two randomised, phase 3 trials. Lancet Oncol 2015; 16:141-51.

14. Douillard JY, Ostoros G, Cobo M, Ciuleanu T, McCormack R, Webster A, Milenkova T. First-line gefitinib in Caucasian EGFR mutation-positive NSCLC patients: a phase-IV, openlabel,single-arm study. Br J Cancer. 2014; 110:55-62.

15. Fukuoka M, Wu YL, Thongprasert S, Sunpaweravong P, Leong SS, Sriuranpong V, Chao TY, Nakagawa K, Chu DT, Saijo N, Duffield EL, Rukazenkov Y, Speake G, et al. Biomarker Analyses and Final Overall Survival Results From a Phase III, Randomized, Open-Label, First-Line Study of Gefitinib Versus Carboplatin/Paclitaxel in Clinically Selected Patients With Advanced Non-Small-Cell Lung Cancer in Asia (IPASS). J Clin Oncol. 2011; 29:2866-74.

16. Han JY, Park K, Kim SW, Lee DH, Kim HY, Kim HT, Ahn MJ, Yun T, Ahn JS, Suh C, Lee JS, Yoon SJ, Han JH, et al. First-SIGNAL: First-Line Single-Agent Iressa Versus Gemcitabine and Cisplatin Trial in Never-Smokers With Adenocarcinoma of the Lung. J Clin Oncol. 2012; 30:1122-8.

17. Inoue A, Kobayashi K, Maemondo M, Sugawara S, Oizumi S, Isobe H, Gemma A, Harada M, Yoshizawa H, Kinoshita I, Fujita Y, Okinaga S, Hirano H, et al. Updated overall survival results from a randomized phase III trial comparing gefitinib with carboplatin-paclitaxel for chemo-naïve non-small cell lung cancer with sensitive EGFR gene mutations(NEJ002). Annals of Oncology. 2012; 00:1-6.

18. Mitsudomi T, Morita S, Yatabe Y, Negoro S, Okamoto I, Tsurutani J, Seto T, Satouchi M, Tada H, Hirashima T, Asami K, Katakami N, Takada M, et al. Gefitinib versus cisplatin plus docetaxel in patients with non-small-cell lung cancer 
harbouring mutations of the epidermal growth factor receptor (WJTOG3405): an open label, randomized phase 3 trial. Lancet Oncol. 2010; 11:121-8.

19. Rosell R, Carcereny E, Gervais R, Vergnenegre A, Massuti B, Felip E, Palmero R, Garcia-Gomez R, Pallares C, Sanchez JM, Porta R, Cobo M, Garrido P, et al. Erlotinib versus standard chemotherapy as first-line treatment for European patients with advanced EGFR mutation-positive non-smallcell lung cancer (EURTAC): a multicentre, open-label, randomised phase 3 trial. Lancet Oncol. 2012; 13:239-46.

20. Zhou C, Wu YL, Chen G, Feng J, Liu XQ, Wang C, Zhang S, Wang J, Zhou S, Ren S, Lu S, Zhang L, Hu C, et al. Erlotinib versus chemotherapy as first-line treatment for patients with advanced EGFR mutation-positive non-small-cell lung cancer (OPTIMAL, CTONG-0802): a multicentre, open-label, randomised, phase 3 study. Lancet Oncol. 2011; 12:735-42.

21. Zhou C, Wu YL, Chen G, Feng JF, Liu X, Wang C. Updated efficacy and quality-of-life(QoL) analyses in OPTIMAL, a phase III, randomized, open-label study of first-line erlotinib versus gemcitabine/carboplatin in patients with EGFRactivating mutation-positive(EGFR Act Mut + ) advanced non-small cell lung cancer (NSCLC) [abstract]. J Clin Oncol. 2011; 29: 7520.

22. Shi Y, Zhang L, Liu X, Zhou C, Zhang L, Zhang S, Wang D, Li Q, Qin S, Hu C, Zhang Y, Chen J, Cheng Y, et al. Icotinib versus gefitinib in previously treated advanced non-small-cell lung cancer (ICOGEN): a randomised, double-blind phase 3 non-inferiority trial. Lancet Oncol 2013; 14:953-61.

23. Shi YK, Wang L, Han BH, Li W, Yu P, Liu Y, Ding C, Song X, Ma Z, Ren X, Feng J, Zhang H,Chen G, et al. First-line icotinib versus cisplatine/pemetrexed plus pemetrexed maintenance therapy in lung adenocarcinoma patients with sensitizing EGFR mutation (CONVINCE). J Clin Oncol. 2016; 34:9041.

24. Yang JC, Hirsh V, Schuler M, Yamamoto N, O’Byrne KJ, Mok TS, Zazulina V, Shahidi M, Lungershausen J, Massey D, Palmer M, Sequist LV. Symptom control and quality of life in LUX-Lung 3: a phase III study of afatinib or cisplatin/ pemetrexed in patients with advanced lung adenocarcinoma with EGFR mutations. J Clin Oncol. 2013; 31:3342-50.

25. Yang JC, Sequist LV, Zhou C, Schuler M, Geater SL, Mok T, Hu CP, Yamamoto N, Feng J, O'Byrne K, Lu S, Hirsh V, Huang Y, et al. Effect of dose adjustment on the safety and efficacy of afatinib for EGFR mutation-positive lung adenocarcinoma: post hoc analyses of the randomized LUXLung 3 and 6 trials. Annals of Oncology 2016; 00:1-8. https:// doi.org/10.1093/annonc/mdw322.

26. Engelman JA, Zejnullahu K, Gale CM, Lifshits E, Gonzales AJ, Shimamura T, Zhao F, Vincent PW, Naumov GN, Bradner JE, Althaus IW, Gandhi L, Shapiro GI, et al. PF00299804, an irreversible pan-ERBB inhibitor, is effective in lung cancer models with EGFR and ERBB2 mutations that are resistant to gefitinib. Cancer Res. 2007; 67:11924-32.

27. Gonzales AJ, Hook KE, Althaus IW, Ellis PA, Trachet E, Delaney AM, Harvey PJ, Ellis TA, Amato DM, Nelson
JM, Fry DW, Zhu T, Loi CM, et al. Antitumor activity and pharmacokinetic properties of PF-00299804, a secondgeneration irreversible pan-erbB receptor tyrosine kinase inhibitor. Mol Cancer Ther. 2008; 7:1880-9.

28. Ramalingam SS, Blackhall F, Krzakowski M, Barrios CH, Park K, Bover I, Seog Heo D, Rosell R, Talbot DC, Frank R, Letrent SP, Ruiz-Garcia A, Taylor I, et al. Randomized phase II study of dacomitinib (PF-00299804), an irreversible pan-human epidermal growth factor receptor inhibitor, versus erlotinib in patients with advanced non-small-cell lung cancer. J Clin Oncol. 2012; 30:3337-44.

29. Kris MG, Mok T, Ou S-HI, Jaenne PA. First-line dacomitinib (PF-00299804), an irreversible pan-HER tyrosine kinase inhibitor, for patients with EGFR-mutant lung cancers. J Clin Oncol. 2012; 30: 7530. https://doi.org/10.1200/ jco.2012.30.15_suppl.7530.

30. Jackman D, Pao W, Riely GJ, Engelman JA, Kris MG, Jänne PA, Lynch T, Johnson BE, Miller VA. Clinical definition of acquired resistance to epidermal growth factor receptor tyrosine kinase inhibitors in non-small-cell lung cancer. J Clin Oncol. 2010; 28:357-60.

31. Kobayashi S, Boggon TJ, Dayaram T, Jänne PA, Kocher O, Meyerson M, Johnson BE, Eck MJ, Tenen DG, Halmos B. EGFR mutation and resistance of non-small-cell lung cancer to gefitinib. N Engl J Med. 2005; 352:786-92.

32. Takezawa K, Pirazzoli V, Arcila ME, Nebhan CA, Song X, de Stanchina E, Ohashi K, Janjigian YY, Spitzler PJ, Melnick MA, Riely GJ, Kris MG, Miller VA, et al. HER2 amplification: a potential mechanism of acquired resistance to EGFR inhibition in EGFR-mutant lung cancers that lack the second-site EGFRT790M mutation. Cancer Discov. 2012; 2:922-33.

33. Uramoto H, Shimokawa H, Hanagiri T, Kuwano M, Ono M. Expression of selected gene for acquired drug resistance to EGFR-TKI in lung adenocarcinoma. Lung Cancer. 2011; 73:361-5.

34. Arcila ME, Oxnard GR, Nafa K, Riely GJ, Solomon SB, Zakowski MF, Kris MG, Pao W, Miller VA, Ladanyi M, et al. Rebiopsy of lung cancer patients with acquired resistance to EGFR inhibitors and enhanced detection of the T790M mutation using a locked nucleic acid-based assay. Clin Cancer Res. 2011; 17:1169-80.

35. Sequist LV, Waltman BA, Dias-Santagata D, Digumarthy S, Turke AB, Fidias P, Bergethon K, Shaw AT, Gettinger S, Cosper AK, Akhavanfard S, Heist RS, Temel J, et al. Genotypic and histological evolution of lung cancers acquiring resistance to EGFR inhibitors. Sci Transl Med. 2011; 3:75ra26.

36. Yu HA, Arcila ME, Rekhtman N, Sima CS, Zakowski MF, Pao W, Kris MG, Miller VA, Ladanyi M, Riely GJ. Analysis of tumor specimens at the time of acquired resistance to EGFR-TKI therapy in 155 patients with EGFR-mutant lung cancers. Clin Cancer Res. 2013; 19:2240-7.

37. Pao W, Miller VA, Politi KA, Riely GJ, Somwar R, Zakowski MF, Kris MG, Varmus H. Acquired resistance of lung adenocarcinomas to gefitinib or erlotinib is associated 
with a second mutation in the EGFR kinase domain. PLoS Med. 2005; 2:e73.

38. Sequist LV, Soria JC, Goldman JW, Wakelee HA, Gadgeel SM, Varga A, Papadimitrakopoulou V, Solomon BJ, Oxnard GR, Dziadziuszko R, Aisner DL, Doebele RC, Galasso C, et al. Rociletinib in EGFR-mutated non-small-cell lung cancer. N Engl J Med 2015; 372:1700-9.

39. Janne PA, Yang JC, Kim DW, Planchard D, Ohe Y, Ramalingam SS, Ahn MJ, Kim SW, Su WC, Horn L, Haggstrom D, Felip E, Kim JH, et al. AZD 9291 in EGFR inhibitor-resistant non-small-cell lung cancer. N Engl J Med. 2015; 372:1689-99.

40. Zhou W, Ercan D, Chen L, Yun CH, Li D, Capelletti M, Cortot AB, Chirieac L, Iacob RE, Padera R, Engen JR, Wong KK,Eck MJ, et al. Novel mutant-selective EGFR kinase inhibitors against EGFR T790M. Nature. 2009; 462:1070-4.

41. Walter AO, Sjin RT, Haringsma HJ, Ohashi K, Sun J, Lee K, Dubrovskiy A, Labenski M, Zhu Z, Wang Z, Sheets M, St Martin T, Karp R, et al. Discovery of a mutant-selective covalent inhibitor of EGFR that overcomes T790M-mediated resistance in NSCLC. Cancer Discov. 2013; 3:1404-15.

42. AstraZeneca. Tagrisso (osimertinib) package insert. Wilmington, DE: AstraZeneca.

43. Oxnard GR, Thress KS, Alden RS, Lawrance R, Paweletz CP, Cantarini M, Yang JC, Barrett JC, Jänne PA. Association between plasma genotyping and outcomes of treatment with osimertinib (AZD9291) in advanced non-small-cell lung cancer. J Clin Oncol. 2016; 34:3375-82.

44. Goss G, Tsai CM, Shepherd FA, Bazhenova L, Lee JS, Chang GC, Crino L, Satouchi M, Chu Q, Hida T, Han JY, Juan O, Dunphy F, et al. Osimertinib for pretreated EGFR Thr790Met-positive advanced non-small-cell lung cancer (AURA2): a multicentre, open-label, single-arm, phase 2 study. Lancet Oncol. 2016; 17:1643-1652.

45. Mok TS, Wu YL, Ahn MJ, Garassino MC, Kim HR, Ramalingam SS, Shepherd FA, He Y, Akamatsu H, Theelen WS, Lee CK, Sebastian M, Templeton A, et al. Osimertinib or platinum-pemetrexed in EGFR T790M-positive lung cancer. N Engl J Med. 2017; 376:629-640.

46. Ramalingam S, Yang JC, Lee CK, Kurata T, Kim DW, John T, Nogami N, Ohe Y, Jänne PA. LBA1_PR: Osimertinib as first-line treatment for EGFR mutation-positive advanced NSCLC: updated efficacy and safety results from two Phase I expansion cohorts. J Thorac Oncol 2016; 11:S152.

47. Sequist LV, Soria JC, Camidge DR. Update to rociletinib data with the RECIST confirmed response rate. N Engl J Med. 2016; 374:2296-7.

48. Park K, Lee JS, Han JY, Lee KH, Kim JH, Cho EK, Cho JY, Min YJ, Kim JS, Kim DW. 1300: Efficacy and safety of BI 1482694 (HM61713), an EGFR mutant-specific inhibitor, in T790M-positive NSCLC at the recommended phase II dose. J Thorac Oncol. 2016; 11:S113.

49. Xu X, Mao L, Xu W, Tang W, Zhang X, Xi B, Xu R, Fang X, Liu J, Fang C, Zhao L, Wang X, Jiang J, et al. AC0010, an Irreversible EGFR Inhibitor Selectively Targeting Mutated EGFR and Overcoming T790M-Induced Resistance in Animal Models and Lung Cancer Patients. Mol Cancer Ther. 2016; 15:2586-2597.

50. Kim D, Lee D, Kang J, Park K, Han JY. Clinical activity and safety of HM61713, an EGFR-mutant selective inhibitor, in advanced nonsmall cell lung cancer (NSCLC) patients (pts) with EGFR mutations who had received EGFR tyrosine kinase inhibitors (TKIs). J Clin Oncol. 2014; 32:abstr 8011.

51. Marukami H. Antitumour activity of ASP8273, an irreversible mutant selective EGFR-TKI, in NSCLC patients with tumours harbouring EGFR activating mutations and T790M resistance mutation. Eur J Cancer. 2014; 50:abstr LBA9.

52. Planchard D, Loriot Y, André F, Gobert A, Auger N, Lacroix L, Soria JC. EGFR-independent mechanisms of acquired resistance to AZD9291 in EGFR T790M-positive NSCLC patients. Ann Oncol. 2015; 26:2073-8.

53. Bersanelli M, Minari R, Bordi P, Gnetti L, Bozzetti C, Squadrilli A, Lagrasta CA, Bottarelli L, Osipova G, Capelletto E, Mor M, Tiseo M. L718Q mutation as new mechanism of acquired resistance to AZD9291 in EGFR-mutated NSCLC. J Thorac Oncol. 2016; 11:e121-3.

54. Thress KS, Paweletz CP, Felip E, Cho BC, Stetson D, Dougherty B, Lai Z, Markovets A, Vivancos A, Kuang Y, Ercan D, Matthews SE,Cantarini M, et al. Acquired EGFR C797S mutation mediates resistance to AZD9291 in nonsmall cell lung cancer harboring EGFR T790M. Nat Med. 2015; 21:560-2.

55. Ercan D, Choi HG, Yun CH, Capelletti M, Xie T, Eck MJ, Gray NS, Jänne PA. EGFR mutations and resistance to Irreversible pyrimidine based EGFR inhibitors. Clin Cancer Res. 2015; 21:3913-23.

56. Niederst MJ, Hu H, Mulvey HE, Lockerman EL, Garcia AR, Piotrowska Z, Sequist LV, Engelman JA. The allelic context of the C797S mutation acquired upon treatment with third generation EGFR inhibitors impacts sensitivity to subsequent treatment strategies. Clin Cancer Res. 2015; 21:3924-33.

57. Wang S, Song Y, Liu D. EAI045: The fourth-generation EGFR inhibitor overcoming T790M and C797S resistance. Cancer Letters. 2017; 385:51-54.

58. Yang JJ, Zhou Q, Yan HH, Zhang XC, Chen HJ, Tu HY, Wang Z, Xu CR, Su J, Wang BC, Jiang BY, Bai XY, Zhong $\mathrm{WZ}$, et al. A randomized controlled trial of erlotinib versus gefitinib in advanced non-small-cell lung cancer harboring EGFR exon 19 or 21 mutations (CTONG0901).16th World Conference on Lung Cancer (WCLC), Denver, United States of America 6-9 September 2015.http://www.nature.com/bjc/ journal/vaop/ncurrent/abs/bjc2016456a.html.

59. Park K, Tan EH, O'Byrne K, Zhang L, Boyer M, Mok T, Hirsh V, Yang JC, Lee KH, Lu S, Shi Y, Kim SW, Laskin $\mathrm{J}$, et al. Afatinib versus gefitinib as first-line treatment of patients with EGFR mutation-positive non-small-cell lung cancer (LUX-Lung 7): a phase 2B, open-label, randomised controlled trial. Lancet Oncol. 2016; 17:577-89. 
60. Paz-Ares L, Tan EH, O'Byrne K, Zhang L, Hirsh V, Boyer M, Yang JC, Mok T, Lee KH, Lu S, Shi Y, Lee DH, Laskin J, et al. Afatinib versus gefitinib in patients with EGFR mutationpositive advanced non-small-cell lung cancer: overall survival data from the phase IIb LUX-Lung 7 trial. Annals of Oncology 0: 1-9, 2017.https://doi.org/10.1093/annonc/ mdw611.

61. Sugawara S, Oizumi S, Minato K, Harada T, Inoue A, Fujita Y, Maemondo M, Yoshizawa H, Ito K, Gemma A, Nishitsuji M, Harada M, Isobe H, et al. Randomized phase II study of concurrent versus sequential alternating gefitinib and chemotherapy in previously untreated non-small cell lung cancer with sensitive EGFR mutations: NEJ005/TCOG0902. Annals of Oncology. 2015; 00:1-7.

62. Wu YL, Lee JS, Thongprasert S, Zhang L, Ladrera G, Srimuninnimit V, Sriuranpong V, Sandoval-Tan J, Zhu Y, Liao M, Zhou C, Pan H, Lee V, et al. Intercalated combination of chemotherapy and erlotinib for patients with advanced stage non-small-cell lung cancer (FASTACT-2): a randomised, double-blind trial. Lancet Oncol. 2013; 14:777-86.

63. Cheng Y, Murakami H, Yang PC, He J, Nakagawa K, Kang JH, Kim JH, Wang X, Enatsu S, Puri T, Orlando M, Yang JC. Randomized Phase II Trial of Gefitinib With and Without Pemetrexed as First-Line Therapy in Patients With Advanced Nonsquamous Non-Small-Cell Lung Cancer With Activating Epidermal Growth Factor Receptor Mutations. J Clin Oncol. 2016; 34:3258-66.

64. Kazushi Y, Yasuhide Y. Erlotinib alone or with bevacizumab as first-line therapy in patients with advanced non-squamous non-small-cell lung cancer harboring EGFR mutations (JO25567): an open-label, randomized, multicenter, phase II study. Transl Lung Cancer Res. 2015; 4:217-9.

65. Sandler A, Gray R, Perry MC, Brahmer J, Schiller JH, Dowlati A, Lilenbaum R, Johnson DH. Paclitaxel-carboplatin alone or with bevacizumab for non-small-cell lung cancer. N Engl J Med. 2006; 355:2542-50.

66. Nilsson M, Heymach JV. Vascular endothelial growth factor (VEGF) pathway. J Thorac Oncol. 2006; 1:768-70.

67. Harari PM, Allen GW, Bonner JA. Biology of interactions: anti-epidermal growth factor receptor agents. J Clin Oncol. 2007; 25:4057-65.

68. Swinson DE, Jones JL, Cox G, Richardson D, Harris AL, O'Byrne KJ. Hypoxia-inducible factor- $1 \alpha$ in non small cell lung cancer: relation to growth factor, protease and apoptosis pathways. Int J Cancer. 2004; 111:43-50.

69. Swinson DE, O'Byrne KJ. Interactions between hypoxia and epidermal growth factor receptor in non-small-cell lung cancer. Clin Lung Cancer. 2006; 7:250-6.

70. Luwor RB, Lu Y, Li X, Mendelsohn J, Fan Z. The anti epidermal growth factor receptor monoclonal antibody cetuximab/C225 reduces hypoxia-inducible factor-1-a, leading to transcriptional inhibition of vascular endothelial growth factor expression. Oncogene. 2005; 24:4433-41.

71. Ciardiello F, Bianco R, Damiano V, Fontanini G, Caputo R, Pomatico G, De Placido S, Bianco AR, Mendelsohn J,
Tortora G. Anti-angiogenic and antitumor activity of antiepidermal growth factor receptor $\mathrm{C} 225$ monoclonal antibody in combination with vascular endothelial growth factor antisense oligonucleotide in human GEO colon cancer cells. Clin Cancer Res. 2000; 6:3739-47.

72. Ciardiello F, Caputo R, Bianco R, Damiano V, Fontanini G, Cuccato S, De-Placido S, Bianco AR, Tortora G. Inhibition of growth factor production and angiogenesis in human cancer cells by ZD1839 (Iressa), a selective epidermal growth factor receptor tyrosine kinase inhibitor. Clin Cancer Res. 2001; 7:1459-65.

73. Pore N, Jiang Z, Gupta A, Cerniglia G, Kao GD, Maity A. EGFR tyrosine kinase inhibitors decrease VEGF expression by both hypoxia inducible factor (HIF)-1independent and HIF-1-dependent mechanisms. Cancer Res. 2006; 66:3197-204.

74. Naumov GN, Nilsson MB, Cascone T, Briggs A, Straume O, Akslen LA, Lifshits E, Byers LA, Xu L, Wu HK, Jänne P, Kobayashi S, Halmos B, et al. Combined Vascular Endothelial Growth Factor Receptor and Epidermal Growth Factor Receptor (EGFR) Blockade Inhibits Tumor Growth in Xenograft Models of EGFR Inhibitor Resistance. Clin Cancer Res. 2009; 15:3484-94.

75. Herbst RS, O’Neill VJ, Fehrenbacher L, Belani CP, Bonomi PD, Hart L, Melnyk O, Ramies D, Lin M, Sandler A. Phase II study of efficacy and safety of bevacizumab in combination with chemotherapy or erlotinib compared with chemotherapy alone for treatment of recurrent or refractory non small-cell lung cancer. J Clin Oncol. 2007; 25:4743-50.

76. Herbst RS, Ansari R, Bustin F, Flynn P, Hart L, Otterson GA, Vlahovic G, Soh CH, O'Connor P, Hainsworth J. Efficacy of bevacizumab plus erlotinib versus erlotinib alone in advanced non-small-cell lung cancer after failure of standard first-line chemotherapy (BeTa): a double-blind, placebo-controlled, phase 3 trial. Lancet. 2011; 377:1846-54.

77. Herbst R, Stern H, Amler L. Biomarker evaluation in the phase III, placebo-controlled, randomized BeTa Trial of bevacizumab and erlotinib for patients with advanced nonsmall cell lung cancer (NSCLC) after failure of standard 1stline chemotherapy: correlation with treatment outcomes. J Thorac Oncol. 2009; 4:S323.

78. Seto T, Kato T, Nishio M, Goto K, Atagi S, Hosomi Y, Yamamoto N, Hida T, Maemondo M, Nakagawa K, Nagase S, Okamoto I, Yamanaka T, et al. Erlotinib alone or with bevacizumab as first-line therapy in patients with advanced non-squamous non-small-cell lung cancer harbouring EGFR mutations (JO25567): an open-label, randomised, multicentre, phase 2 study. Lancet Oncol. 2014; 15:1236-44.

79. Rolf Stahel.A phase II trial of erlotinib (E) and bevacizumab (B) in patients with advanced non-small-cell lung cancer (NSCLC) with activating epidermal growth factor receptor (EGFR) mutations with and without T790M mutation. Lancet Oncol. 2015, Published online October 6, 2015.http://dx.doi. org/10.1016/s1470-204500378.2.

80. Brahmer J, Reckamp KL, Baas P, Crinò L, Eberhardt WE, Poddubskaya E, Antonia S, Pluzanski A, Vokes EE, Holgado 
E,Waterhouse D, Ready N, Gainor J, et al. Nivolumab versus docetaxel in advanced squamous-cell non-small-cell lung cancer. N Engl J Med. 2015; 373:123-35.

81. Borghaei H, Paz-Ares L, Horn L, Spigel DR, Steins M, Ready NE, Chow LQ, Vokes EE, Felip E, Holgado E, Barlesi F, Kohlhäufl M, Arrieta $\mathrm{O}$, et al. Nivolumab versus docetaxel in advanced nonsquamous non-small-cell lung cancer. N Engl J Med. 2015; 373:1627-39.

82. Garon EB, Rizvi NA, Hui R, Leighl N, Balmanoukian AS, Eder JP, Patnaik A, Aggarwal C, Gubens M, Horn L, Carcereny E, Ahn MJ, Felip E, et al. Pembrolizumab for the treatment of non-small-cell lung cancer. N Engl J Med. 2015; 372:2018-28.

83. Akbay EA, Koyama S, Carretero J, Altabef A, Tchaicha JH, Christensen CL, Mikse OR, Cherniack AD, Beauchamp EM, Pugh TJ, Wilkerson MD, Fecci PE, Butaney M, et al. Activation of the PD-1 pathway contributes to immune escape in EGFR-driven lung tumors. Cancer Discov. 2013; 3:1355-63.

84. Azuma K, Ota K, Kawahara A, Hattori S, Iwama E, Harada T, Matsumoto K, Takayama K, Takamori S, Kage M, Hoshino T, Nakanishi Y, Okamoto I. Association of PD-L1 over expression with activating EGFR mutations in surgically resected non small-cell lung cancer. Ann Oncol. 2014; 25:1935-40.

85. D'Incecco A, Andreozzi M, Ludovini V, Rossi E, Capodanno A, Landi L, Tibaldi C, Minuti G, Salvini J, Coppi E, Chella A, Fontanini G, Filice ME, et al. PD-1 and PD-L1 expression in molecularly selected non-small-cell lung cancer patients. $\mathrm{Br}$ J Cancer. 2015; 112:95-102.

86. Tang Y, Fang W, Zhang Y, Hong S, Kang S, Yan Y, Chen N, Zhan J, He X, Qin T, Li G, Tang W, Peng P, et al. The association between PD-L1 and EGFR status and the prognostic value of PD-L1 in advanced non-small cell lung cancer patients treated with EGFR-TKIs. Oncotarget. 2015; 6:14209-19. https://doi.org/10.18632/oncoctarget.3694.

87. Han JJ, Kim DW, Koh J, Keam B, Kim TM, Jeon YK, Lee $\mathrm{SH}$, Chung DH, Heo DS. Change in PD-L1 expression after acquiring resistance to gefitinib in EGFR-mutant non-smallcell lung cancer. Clin Lung Cancer. 2016; 17:263-270.e2.

88. Ahn MJ, Yang J, Yu H, Saka H, Ramalingam S, Goto K, Kim SW, Yang L, Walding A, Oxnard GR. 136O: osimertinib combined with durvalumab in EGFR-mutant non-small cell lung cancer: results from the TATTON phase Ib trial. J Thorac Oncol. 2016; 11:S115.

89. Gibbons DL, Chow LQ, Kim DW, Kim SW, Yeh T, Song X, Jiang H, Taylor R, Karakunnel J, Creelan B. 57 O Efficacy, safety and tolerability of MEDI4736 (durvalumab [D]), a human IgG1 anti-programmed cell death-ligand-1 (PD-L1) antibody, combined with gefitinib (G): a phase I expansion in TKI-naive patients (pts) with EGFR mutant NSCLC. J Thorac Oncol. 2016; 11:S79.

90. Shackleton M, Quintana E, Fearon ER, Morrison SJ. Heterogeneity in cancer: cancer stem cells versus clonal evolution. Cell. 2009; 138:822-829.https://doi.org/10.1016/j. cell.2009.08.017.

91. Swanton C. Intratumor heterogeneity: evolution through space and time. Cancer Res. 2012; 72:4875-4882. https:// doi.org/10.1158/0008-5472.CAN-12-2217.

92. Merlo LM, Pepper JW, Reid BJ. Cancer as an evolutionary and ecological process. Nat Rev Cancer. 2006; 6:924-935. https://doi.org/10.1038/nrc2013.

93. Jamal-Hanjani M, Wilson GA, McGranahan N, Birkbak NJ, Watkins TBK, Veeriah S, Shafi S, Johnson DH, Mitter R, Rosenthal R, Salm M, Horswell S, Escudero M, et al. Tracking the Evolution of Non-Small-Cell Lung Cancer. N Engl J Med. 2017; 376:2109-2121. https://doi.org/10.1056/ NEJMoa1616288.

94. Jamal-Hanjani M, Hackshaw A, Ngai Y, Shaw J, Dive C, Quezada S, Middleton G, de Bruin E, Le Quesne J, Shafi S, Falzon M, Horswell S, Blackhall F, et al. Tracking genomic cancer evolution for precision medicine: the lung TRACERx study. PLoS Biol. 2014; 12:e1001906. https://doi. org/10.1371/journal.pbio.1001906.

95. Abbosh C, Birkbak NJ, Wilson GA, Jamal-Hanjani M, Constantin T, Salari R, Le Quesne J, Moore DA, Veeriah S, Rosenthal R, Marafioti T, Kirkizlar E, Watkins TBK, et al. Phylogenetic ctDNA analysis depicts early stage lung cancer evolution. Nature. http://dx.doi.org/10.1038/nature22364.

96. Douillard JY, Ostoros G, Cobo M, Ciuleanu T, Cole R, McWalter G, Walker J, Dearden S, Webster A, Milenkova T, McCormack R. Gefitinib treatment in EGFR mutated caucasian NSCLC: Circulating-free tumor DNA as a surrogate for determination of EGFR status. J Thorac Oncol. 2014; 9:1345-53.

97. Mao C, Yuan JQ, Yang ZY, Fu XH, Wu XY, Tang JL. Blood as a substitute for tumor tissue in detecting EGFR mutations for guiding EGFR TKIs treatment of non small cell lung cancer: A systematic review and meta-analysis. Medicine (Baltimore) 2015; 94:e775.

98. Sueoka-Aragane N, Katakami N, Satouchi M, Yokota S, Aoe K, Iwanaga K, Otsuka K, Morita S, Kimura S, Negoro S. Monitoring EGFR T790M with plasma DNA from lung cancer patients in a prospective observational study. Cancer Sci. 2016; 107:162-7.

99. Lee JY, Qing X, Xiumin W, Yali B, Sangah C, So HB, Ho YL, Sun JM, Lee SH, Seok JA, Cho EK, Kim DW, Kim HR, et al. Longitudinal monitoring of EGFR mutations in plasma predicts outcomes of NSCLC patients treated with EGFR TKIs: Korean Lung Cancer Consortium(KLCC-12-02). Oncotarget. 2016; 7:6984-93.

100. Xu S, Lou F, Wu Y, Sun DQ, Zhang JB, Chen W, Ye H, Liu JH, Wei S, Zhao MY, Wu WJ, Su XX, Shi R, et al. Circulating tumor DNA identified by targeted sequencing in advancedstage non-small cell lung cancer patients. Cancer Lett. 2016; 370:324-31.

101. Jamal-Hanjani M, Wilson GA, Horswell S, Mitter R, Sakarya O, Constantin T, Salari R, Kirkizlar E, Sigurjonsson S, 
Pelham R, Kareht S, Zimmermann B, Swanton C. Detection of ubiquitous and heterogeneous mutations in cell-free DNA from patients with early-stage non-small-cell lung cancer. Ann Oncol. 2016; 27:862-7.

102. Xu T, Kang X, You X, Dai L, Tian D, Yan W, Yang Y, Xiong H, Liang Z, Zhao GQ, Lin S, Chen KN, Xu G. Cross-Platform
Comparison of Four Leading Technologies for Detecting EGFR Mutations in Circulating Tumor DNA from Non-Small Cell Lung Carcinoma Patient Plasma. Theranostics. 2017 7:1437-1446. 